\title{
Effects of flooding regimes on the decomposition and nutrient dynamics of Calamagrostis angustifolia litter in the Sanjiang Plain of China
}

\author{
Zhigao Sun $\cdot$ Xiaojie Mou $\cdot$ Jing Shuang Liu
}

Received: 11 January 2011/ Accepted: 3 November 2011/Published online: 15 November 2011

(C) The Author(s) 2011. This article is published with open access at Springerlink.com

\begin{abstract}
From May 2005 to September 2006, the potential effects of marsh flooding regimes on the decomposition and nutrient (N, P) dynamics of Calamagrostis angustifolia litter were studied in the typical waterlogged depression in the Sanjiang Plain, Northeast China. The decomposition of $C$. angustifolia litter was related to four sites with different hydrologic regimes [F1 (perennial flooding, average water depth of 480 days was $40.14 \pm 8.93 \mathrm{~cm}$ ), F2 (perennial flooding $33.27 \pm$ $6.67 \mathrm{~cm}$ ), F3 (perennial flooding $23.23 \pm 5.65 \mathrm{~cm}$ ) and F4 (seasonal flooding $1.02 \pm 1.09 \mathrm{~cm}$ )]. Results showed that flooding regimes had important effects on the litter decomposition, the decomposition rates differed among the four sites, in the order of F3 $\left(0.001820 \mathrm{~d}^{-1}\right)>\mathrm{F} 1$ $\left(0.001210 \mathrm{~d}^{-1}\right)>$ F2 $\left(0.001040 \mathrm{~d}^{-1}\right)>\mathrm{F} 4 \quad\left(0.000917 \mathrm{~d}^{-1}\right)$, and the values in the perennial flooding regimes were much higher. Flooding regimes also had significant effects on the $\mathrm{N}$ and $\mathrm{P}$ dynamics of litter in decomposition process. If the perennial flooding regimes were formed in C. angustifolia
\end{abstract}

\section{Z. Sun $(\bowtie) \cdot X$. Mou}

Key laboratory of Coastal Environment Processes,

Chinese Academy of Sciences, Shandong Provincial Key

Laboratory of Coastal Zone Environmental Processes,

Yantai Institute of Coastal Zone Research,

Chinese Academy of Sciences,

Yantai 264003, People's Republic of China

e-mail: zgsun@yic.ac.cn

\section{Mou $\cdot$ J. S. Liu}

Key Laboratory of Wetland Ecology and Environment, Northeast Institute of Geography and Agroecology, Chinese Academy of Sciences, Changchun 130012, People's Republic of China

X. Mou

Graduate University of Chinese Academy of Sciences, Beijing 100039, People's Republic of China wetland due to the changes of precipitation in the future, the litter mass loss would increase $23.28-48.88 \%$, the decomposition rate would increase $13.41-98.47 \%$, and the $t_{0.95}$ would decrease $1.07 \mathrm{yr}-4.50 \mathrm{yr}$. In the perennial flooding regimes, the net $\mathrm{N}$ accumulated in some periods, while the net $\mathrm{P}$ released at all times. This study also indicated that the changes of $\mathrm{N}$ and $\mathrm{P}$ content in the litter of the four flooding regimes were probably related to the $\mathrm{C} / \mathrm{N}$ or $\mathrm{C} / \mathrm{P}$ ratios in the litter and the $\mathrm{N}$ or $\mathrm{P}$ availability in the decomposition environment. If the nutrient status of the decomposition environment did not change greatly, the decomposition rates depended on the substrate quality indices of the litter. Conversely, if the nutrient status changed greatly, the decomposition rates might depend on the supply status of nutrient in the decomposition environment.

Keywords Litter decomposition - Flooding regime . Calamagrostis angustifolia · Nitrogen · Phosphorus . Sanjiang Plain

\section{Introduction}

Nutrient cycles and energy flow are two important fields of ecosystem research. Litter decomposition is an important link of nutrient cycling, and connects the synthesis (photosynthesis) and decomposition (the breakdown of organic matter and the release of nutrient elements) of biological organisms (Peng and Liu 2002). Wetlands are the most active interfaces for energy and nutrient movement on the earth since they are the ecotones between waters and lands (Chen 1995). The decomposition rates of litter in wetland ecosystems, to a great extent, affect the accumulation rates of litter and the return of nitrogen $(\mathrm{N})$, phosphorus $(\mathrm{P})$ and other elements to the soil pool. This process even affects 
the germination, growth, species abundance and aboveground biomass of wetland plants, and further influences the composition of plant community and the competition among populations in the habitat (Yin et al. 1994; Peng and Liu 2002).

At present, many studies on the litter decomposition process in wetland ecosystems have been reported, and the research objects have related to freshwater marsh (Vargo et al. 1998; Villar et al. 2001; Anderson and Smith 2002; Welsch and Yavitt 2003; Xie et al. 2004), salt marsh (Mendelssohn et al. 1999; Bouchard and Lefeuvre 2000; Pereira et al. 2007), mangrove swamp (Holmboe et al. 2001; Dick and Osunkoya 2000; Tam et al. 1998; Nielsen and Andersen 2003) and peat bog (Haraguchi et al. 2002, 2003; Freeman et al. 2004; Laiho et al. 2004). Overall, the current research not only relates to the litter decomposition characteristics, the changes of organic matter composition and element [such as nitrogen $(\mathrm{N})$, phosphorus $(\mathrm{P})$, potas$\operatorname{sium}(\mathrm{K})$, sulphur(S)] contents in litter in the decomposition process, but also focuses on the responses of litter decomposition to global changes (Cotrufo et al. 1998; Dilustro et al. 2002; Sowerby et al. 2005). Understanding the response of litter decomposition to global changes is of crucial importance in understanding soil organic matter formation and carbon sequestration in wetland ecosystems. In general, the studies on the response of litter decomposition to global changes have been widely carried out in grassland ecosystem (Owensby 1993; Wang et al. 2000; Alwyn et al. 2005), forest ecosystem (Berg et al. 2000; Finzi et al. 2001) and agroecosystem (Marhan et al. 2008; Liu et al. 2009) through long-term ground network monitoring and observation, freeair $\mathrm{CO}_{2}$ enrichment (FACE) technique, simulating climatic change experiments in situ, cross-site decomposition experiments and application of reciprocal transplant technique across different climate zones. However, the information on the response of litter decomposition to the global changes in wetland ecosystems is still very limited.

Hydrology is suspected of a major role in litter decomposition process of wetland ecosystems, which mainly affects the transformation of organic matter indirectly through altering the aeration of litter (Cai 2000). Edward and Day (1990) studied the decomposition of roots in the periodically flooded Great Dismal Swamp, and demonstrated that the root decay was slowest on the sites with the longest duration of soil saturation (Chamaecyparis thyoides and Acer rubrum-Nyssa ssp.). But Lin et al. (2004) found that dissolved oxygen (DO) depletion associated with organic matter decomposition took place rapidly in the floodwater inundating the soils. Wrubleski et al. (1997) indicated that there were few differences in dry mass loss of four emergent macrophytes litters (Typha glauca, Phragmites australis, Scolochloa festucacea and Scirpus lacustris) in unflooded or flooded soils, and depth of flooding also had little effect on decomposition rates. The wet-dry cycles also had important effects on litter decomposition. Anderson and Smith (2002) found that the natural wet-dry cycles in playa wetland enhanced the decomposition process of Polygonum pensylvanicum litter. However, Laiho et al. (2004) indicated that the mass loss was faster in undrained versus drained sites for Pinus sylvestris litter. Generally, the effects of wet-dry cycles on litter decomposition mainly depended on the range and time of water table fluctuation. Haraguchi et al. (2003) indicated that the cellulose decomposition rates were positively correlated with the range of water table fluctuation. Anderson and Smith (2002) found that the decomposition rates of $P$. pensylvanicum litter were generally lowest in the long-term flooded conditions and highest in the short-term flooded conditions. Although the researches mentioned above have provided many important results, the information about the effects of hydrological condition on litter decomposition is unclear, and further studies are still needed.

Calamagrostis angustifolia wetland is the main wetland type (accounts for $34.45 \%$ of the wetland) in the Sanjiang Plain of Northeast China (He 2000), which is predominated by $C$. angustifolia species ( $>83 \%$ ), with the remaining of the vegetation $(<17 \%)$ constituted by Salix myrtilloides, Sium suave and Gentiana scabra, etc (Ji 2004). The C. angustifolia wetland is located on the edge of waterlogged depression which is the most typical distribution in the Sanjiang Plain. In general, the waterlogged depression is relatively closed and usually separated by embankments or ditches resulting from human activities ( $\mathrm{Lu}$ et al. 2008). There is almost no water imported by runoff, and precipitation is the main source of marsh water. Therefore, the C. angustifolia wetland is very sensitive to the changes of water conditions caused by precipitation. At present, some studies on the decomposition of $C$. angustifolia litter already have been reported, but these studies mainly focused on the research of decomposition characteristics and common affecting factors (Liu et al. 2000; Gao et al. 2004; Yang et al. 2006; Wu et al. 2007), and the relative studies about the effects of flooding regime on $C$. angustifolia litter decomposition are very scarce. According to the studies using IPCC AR4 models (under scenarios A2 and B1) (IPCC 2007), precipitation in northeast China in the future presents increasing tendency (Wang et al. 2009), and extreme precipitation events or precipitation intensity also will be increased (Jiang et al. 2009), indicating that the water conditions of $C$. angustifolia wetland are likely to change greatly in the future. Therefore, in the background of global change, how to predict the effects of flooding regimes, caused by the changes of precipitation, on the decomposition of $C$. angustifolia litter is an important question in understanding the ecological process and mechanism of $C$. angustifolia wetland in the future. 
In this paper, the litterbag technique was used, and the natural flooding regimes in the waterlogged depression were applied to simulate the changes of water conditions in C. angustifolia wetland. The purposes of this paper were (i) to predict the potential effects of different flooding regimes, caused by the changes of precipitation in the future, on the decomposition of C. angustifolia litter; (ii) to study the probable dynamic characteristics of nutrient $(\mathrm{N}$, $\mathrm{P}$ ) in $C$. angustifolia litter as the different flooding regimes were formed in the future.

\section{Materials and methods}

\section{Study site}

The experiment was carried out at the Ecological Experiment Station of Mire Wetland in the Sanjiang Plain, Chinese Academy of Sciences $\left(47^{\circ} 35^{\prime} \mathrm{N}, 133^{\circ} 31^{\prime} \mathrm{E}\right)$, which is located in northeast of Heilongjiang province of China (Chen 1996). The experimental field (about 1,000 ha ${ }^{2}$ ) is located in the floodplain between Bielahong River and Nongjiang River, at an altitude of $56 \mathrm{~m}$. The experimental field is of typical continental monsoon climate, summer is warm and rainy while winter is long-term cold. The frozen depth of soil in winter is about $1.8-2.2 \mathrm{~m}$. The annual average temperature is $1.9^{\circ} \mathrm{C}$, and the effective accumulative temperature is about $2,300^{\circ} \mathrm{C}$. The annual evaporation is $542-580 \mathrm{~mm}$, the annual precipitation is $565-600 \mathrm{~mm}$ and about $60 \%$ of precipitation occurs between June and August (Liu et al. 2003). The experimental field is a waterlogged depression which is the most typical distribution in the Sanjiang Plain. From centre to outside, the vegetations in the waterlogged depression are circularly distributed with Carex pseudocuraica, Carex lasiocarpa, Carex meyeriana and $C$. angustifolia. Because the water adaption ranges differed among the four communities, in the order of $C$. pseudocuraica $>$ C. lasiocarpa $>$ Carex meyeriana $>C$. angustifolia, the distribution and succession of different communities are significantly affected by the changes of water conditions caused by precipitation (Yang and Lu 1996). If water condition in a community exceeds its adaption range, the vegetation will disappear and be replaced by other vegetations gradually (Zhang 1988). The soils at the experimental field are of humus marsh soil and meadow marsh soil, and the characteristics of topsoil $(0-20 \mathrm{~cm})$ in different communities are showed in Table 1 . In this study, the annual average production of $C$. angustifolia litter is 1,027.7 \pm $202.9 \mathrm{~g} \mathrm{~m}^{-2}$, and the total carbon (TC), total nitrogen (TN), total phosphorus (TP) and total sulfur (TS) contents in $C$. angustifolia litter are $41.24 \pm 2.81 \%, 4,505.7 \pm 100.3$, $656.2 \pm 67.6$ and $752.2 \pm 141.7 \mathrm{mg} \mathrm{kg}^{-1}$, respectively.

Study method

As the flooding conditions of waterlogged depression, from centre to outside, represents different hydrologic regimes, it can be used to study the different changes of water regimes in C. angustifolia wetland caused by precipitation in the future. From May 2005 to September 2006, the decomposition experiment of $C$. angustifolia litter was conducted with litterbag technique in four different sites (F1, F2, F3 and F4) in waterlogged depression. The water regime in each site was classified, based on 480 days, water depth (only determined in unfrozen period) and flooding time, as F1 (perennial flooding, average water depth of 480 days was $40.14 \pm 8.93 \mathrm{~cm}$ ), F2 (perennial flooding, $33.27 \pm$ $6.67 \mathrm{~cm}$ ), F3 (perennial flooding, $23.23 \pm 5.65 \mathrm{~cm}$ ) and F4 (seasonal flooding, the abundant precipitation, in the growing season, generally occurs in summer (between June and August), and the $C$. angustifolia community is usually flooded by shallow water. While in early spring (May) and autumn (September and October), the community usually has no standing water due to the low precipitation, $(1.02 \pm 1.09 \mathrm{~cm})$, according to the natural hydrologic conditions observed during the study (Fig. 1). The four water regimes (represented by water depth) during the experiment had significant different $(p<0.01)$. Precipitation during the

Table 1 Basic characteristics of topsoil $(0-20 \mathrm{~cm})$ in different communities

\begin{tabular}{lllllllll}
\hline Communities & Soil types & $\begin{array}{l}\text { Soil bulk } \\
\text { density } \\
\left(\mathrm{g} \mathrm{cm}^{-3}\right)\end{array}$ & $\mathrm{pH}$ & $\begin{array}{l}\text { Organic } \\
\text { matter }(\%)^{\mathrm{a}}\end{array}$ & $\begin{array}{l}\text { Total } \\
\text { phosphorus } \\
\left(\mathrm{g} \mathrm{kg}^{-1}\right)^{\mathrm{a}}\end{array}$ & $\begin{array}{l}\text { Total nitrogen } \\
\left(\mathrm{g} \mathrm{kg}^{-1}\right)^{\mathrm{a}}\end{array}$ & $\begin{array}{l}\text { Ammonium } \\
\text { nitrogen } \\
\left(\mathrm{mg} \mathrm{kg}^{-1}\right)^{\mathrm{a}}\end{array}$ & $\begin{array}{l}\text { Nitrate } \\
\text { nitrogen } \\
\left(\mathrm{mg} \mathrm{kg}^{-1}\right)^{\mathrm{a}}\end{array}$ \\
\hline $\begin{array}{c}\text { Calamagrostis } \\
\text { angustifolia } \\
\text { Carex meyeriana }\end{array}$ & $\begin{array}{c}\text { Meadow } \\
\text { marsh soil }\end{array}$ & 0.91 & 5.37 & $14.03 \pm 6.00$ & $99.59 \pm 35.38$ & $806.77 \pm 396.83$ & $18.97 \pm 11.20$ & $0.97 \pm 0.19$ \\
$\begin{array}{c}\text { Humus marsh } \\
\text { soil }\end{array}$ & 0.73 & 5.93 & $29.80 \pm 8.05$ & $137.76 \pm 3.71$ & $1,592.60 \pm 308.34$ & $38.87 \pm 24.54$ & $1.04 \pm 0.25$ \\
Carex lasiocarpa & $\begin{array}{c}\text { Humus marsh } \\
\text { soil }\end{array}$ & 0.57 & 5.36 & $51.24 \pm 3.53$ & $96.21 \pm 12.65$ & $2,247.30 \pm 175.26$ & $31.79 \pm 3.54$ & $2.29 \pm 0.21$ \\
$\begin{array}{c}\text { Carex } \\
\text { pseudocuraica }\end{array}$ & $\begin{array}{c}\text { Humus marsh } \\
\text { soil }\end{array}$ & 0.35 & 6.37 & $53.79 \pm 0.13$ & $112.11 \pm 3.38$ & $1,456.05 \pm 24.00$ & $28.98 \pm 2.65$ & $2.40 \pm 0.14$ \\
\hline
\end{tabular}

\footnotetext{
${ }^{a}$ Values are means $( \pm \mathrm{SD}, n=5)$
} 


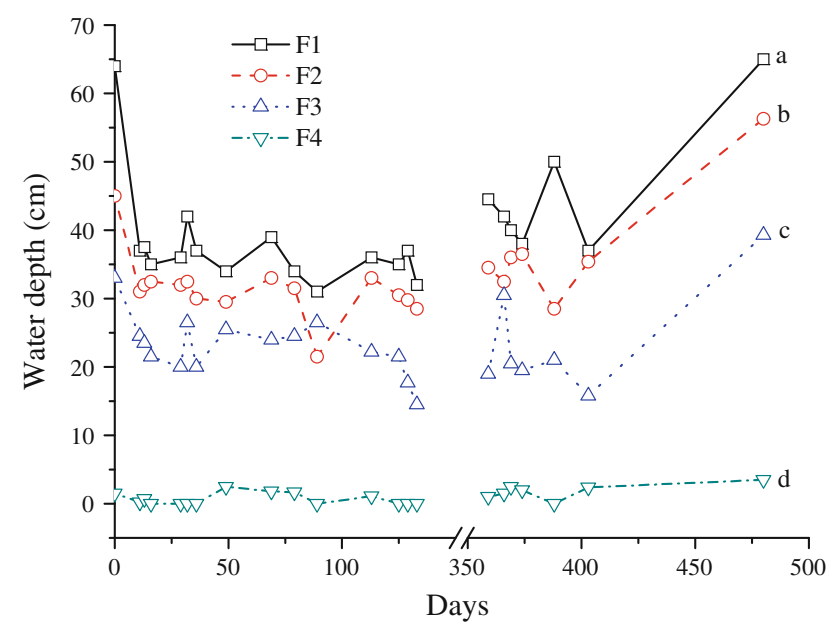

Fig. 1 Water depth through time for four sites with varying flooding regimes [F1 (perennial flooding, average water depth of 480 days was $40.14 \pm 8.93 \mathrm{~cm}$ ), F2 (perennial flooding, $33.27 \pm 6.67 \mathrm{~cm}$ ), F3 (perennial flooding, $23.23 \pm 5.65 \mathrm{~cm}$ ) and $\mathrm{F} 4$ (seasonal flooding, $1.02 \pm 1.09 \mathrm{~cm}$ )] in the waterlogged depression, 25 May 2005-25 September 2006. Values with the same letters are not significantly different at $p<0.05$

growing season (May-October) in 2005 and 2006 were 388.6 and $518.7 \mathrm{~mm}$, respectively.

The $C$. angustifolia litter was collected from the C. angustifolia community at the end of April 2005. In order to weaken the fragmentation impact of heavy snowfalls and strong winds in winter, the standing litter was selected for use in this study. The litter was washed in distilled water, cut into $10 \mathrm{~cm}$ segments and oven-dried at $80^{\circ} \mathrm{C}$ for $48 \mathrm{~h}$. Each $20 \mathrm{~cm} \times 20 \mathrm{~cm}$ litterbag was made of nylon netting $(0.5 \mathrm{~mm}$ mesh) and was filled with $15 \mathrm{~g}$ (oven-dried weight) litter. The litterbags were randomly placed on the ground of above-mentioned sites (more than 36 litterbags were placed in each site) on May 25, 2006. Five litterbags were regularly retrieved from each sampling site during the following 480 days, with a total of 20 litterbags for each time. After retrieval, these litterbags were immediately taken back to the laboratory, and the plant roots, lichen, sediment and macro-invertebrates were removed from the remaining litter. Finally, all litterbags were further cleaned gently in deionized water. The samples were dried at $80^{\circ} \mathrm{C}$ for $48 \mathrm{~h}$, weighed and ground $(<0.25 \mathrm{~mm})$ using a Wiely mill and analyzed for TC, TN contents by element analyzer (Elementar Vario Micro, Germany) and TP content by molybdate-ascorbic acid colorimetry (digested by $\mathrm{H}_{2} \mathrm{SO}_{4}$ $\mathrm{H}_{2} \mathrm{O}_{2}$ ) (The Committee of Agro-chemistry of the Chinese Society of Soil Science 1983).

Determination of environmental factors

During the experiment, the atmospheric temperature, ground/water temperature $(0,5,10,20 \mathrm{~cm}$ depth $)$ and soil/ water $\mathrm{pH}$ were periodically determined. Marsh water was sampled per month in $\mathrm{F} 1, \mathrm{~F} 2$ and $\mathrm{F} 3$ for analyzing the TN, $\mathrm{TP}, \mathrm{NH}_{4}{ }^{+}-\mathrm{N}, \mathrm{NO}_{3}{ }^{-}-\mathrm{N}, \mathrm{NO}_{2}{ }^{-}-\mathrm{N}$ and $\mathrm{PO}_{4}{ }^{3-}{ }^{-} \mathrm{P}$ contents with conventional methods (The Committee of Agro-chemistry of the Chinese Society of Soil Science 1983). Since the majority dates of the water samples from April to September in 2006 were incomplete, the corresponding dates used in this study were from May to September in 2005.

\section{Calculation and statistical analysis}

Litter decomposition rate was calculated by the following exponential model (Olson 1963):

$W_{\mathrm{t}} / W_{0}=e^{-k t}$

where $W_{0}$ is the original dry mass $(\mathrm{g}), W_{\mathrm{t}}$ is the mass remaining at time " $t$ ", $k$ is the decay constant and $t$ is decomposition time in days. Differences in decomposition rates among the flooding regime treatments were determined by comparing the decay constant " $k$ ".

The $\mathrm{N}$ accumulation index (NAI) and $\mathrm{P}$ accumulation index (PAI) were used to express the accumulation or release status of nutrient $(\mathrm{N}, \mathrm{P})$ in litter in decomposition process, which could be calculated by the following equation:

$\mathrm{AI}=\frac{M_{i} \cdot X_{i}}{M_{0} \cdot X_{0}} \times 100 \%$

where $M_{0}$ is the original dry mass, $X_{0}$ is the original nutrient content in litter, $M_{i}$ is the dry mass at time " $i$ " and $X_{i}$ is the nutrient content in litter at time " $i$ ". AI $>100 \%$ indicated that net nutrient accumulated in litter, whereas $\mathrm{AI}<100 \%$ indicated that net nutrient released from litter.

The samples were presented as means over the replications, with standard deviation (SD). The analysis of variance (ANOVA) tests (SPSS for windows 11.0) was employed to determine if treatments differed significantly $(p<0.05)$. If ANOVA showed significant differences, multiple comparison of means was undertaken by Tukey's test with a significance level of $p=0.05$.

\section{Results}

Dynamics of nutrient contents in marsh water of the four sites

The dynamics of TN, TP, $\mathrm{NH}_{4}{ }^{+}-\mathrm{N}, \mathrm{NO}_{3}{ }^{-}-\mathrm{N}, \mathrm{NO}_{2}{ }^{-}-\mathrm{N}$ and $\mathrm{PO}_{4}{ }^{3-}-\mathrm{P}$ contents in the marsh water of $\mathrm{F} 1, \mathrm{~F} 2$ and $\mathrm{F} 3$ from May to September in 2005 showed that the $\mathrm{N}$ and $\mathrm{P}$ nutrient status of the three sites were different (Fig. 2), but the differences were not significant. In general, the TN content was higher in F3 site, while in F1 site, the TP content was much higher. 


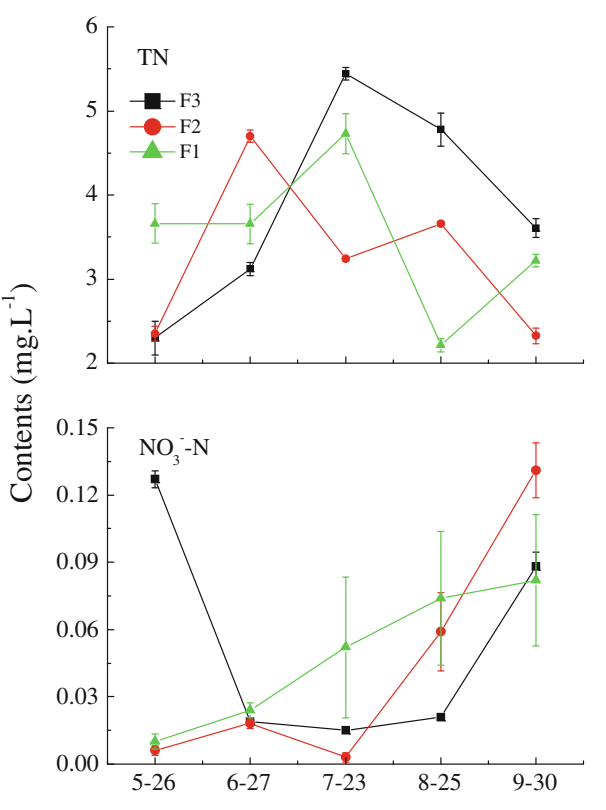

Fig. 2 Changes of TN, TP, $\mathrm{NH}_{4}{ }^{+}-\mathrm{N}, \mathrm{NO}_{3}{ }^{-}-\mathrm{N}, \mathrm{NO}_{2}{ }^{-}-\mathrm{N}$ and $\mathrm{PO}_{4}{ }^{3-}$ contents in marsh water of the four sites with varying flooding regimes [F1 (perennial flooding, average water depth of 480 days was $40.14 \pm 8.93 \mathrm{~cm}$ ), F2 (perennial flooding, $33.27 \pm 6.67 \mathrm{~cm}$ ), F3

\section{Dynamics of litter decomposition}

The mass loss of $C$. angustifolia litter in the four sites were rapid in summer and fall (accounting for 58.74, 54.99, 85.14 and $90.87 \%$ of annual loss for F4, F3, F2 and F1, respectively), while slow or even inactive in winter and early spring except F4 and F3 (Fig. 3). After 480 days, the percent of dry mass remaining was $59.01 \pm 7.50 \%$ for $\mathrm{F} 4,38.97 \pm 8.60 \%$ for $\mathrm{F} 3$, $49.47 \pm 0.72 \%$ for $\mathrm{F} 2$ and $47.65 \pm 1.76 \%$ for $\mathrm{F} 1$. The mass loss of litter in different sites presented $\mathrm{F} 2 \approx \mathrm{F} 1>\mathrm{F} 3>\mathrm{F} 4$ from 0 to 220 days and $\mathrm{F} 3>\mathrm{F} 2 \approx \mathrm{F} 1>\mathrm{F} 4$ from 220 to 480 days, indicating that flooding regime had important effects on the litter decomposition. The decomposition rates differed among the four sites, in the order of $\mathrm{F} 3$ $\left(0.001820 \mathrm{~d}^{-1}\right)>\mathrm{F} 1\left(0.001210 \mathrm{~d}^{-1}\right)>\mathrm{F} 2\left(0.001040 \mathrm{~d}^{-1}\right)>$ F4 $\left(0.000917 \mathrm{~d}^{-1}\right)$ and the values in the perennial flooding regimes were much higher (Table 2). If the perennial flooding regimes were formed in C. angustifolia wetland in the future, the litter mass loss would increase $23.28-48.88 \%$, the decomposition rate would increase $13.41-98.47 \%$, and the $t_{0.95}$ would decrease $1.07 \mathrm{yr}-4.50 \mathrm{yr}$.

Nutrient dynamics in litter decomposition process

\section{Dynamics of total nitrogen and total phosphorus content}

The TN content in C. angustifolia litter of F4 had no significantly changed except for one obvious decline occurred in 420 days (Fig. 4a), and after 480 days, the value was very close to the initial one. Comparatively, the TN content in the litter of F3, F2 and F1 changed consistently with a significant peak observed in 120 days, and over 480 days, the values were $1.80,1.13$ and 1.43 times the initial ones, respectively. ANOVA showed that the TN contents in litter of the four flooding regimes had no significant difference $(p>0.05)$.

The TP content in litter of F4 increased rapidly to 2.15 times the initial value at the first month, and then changed steadily from 30 to 60 days (Fig. 4b). After that, the TP content decreased although little fluctuation was observed from 90 to 360 days, and the value in litter, over 480 days, was only 0.35 times the initial one. Comparatively, the TP content in the litter of F3, F2 and F1 changed consistently from 0 to 120 days, accounting for 34.60-89.57, 49.99-90.14 and $55.04-77.98 \%$ of the initial value, respectively. From 120 to 480 days, the values of F3, F2 and F1 changed differently and, over 480 days, an obvious increase observed in F3 and F2, while a significant decrease occurred in F1. ANOVA showed that the TP contents in litter of the four flooding regimes had significant difference $(p<0.05)$.

\section{Dynamics of $C / N$ and $C / P$ ratio}

In the perennial flooding regimes (F1, F2 and $\mathrm{F} 3), \mathrm{C} / \mathrm{N}$ ratios were much lower and $\mathrm{C} / \mathrm{P}$ ratios were generally 


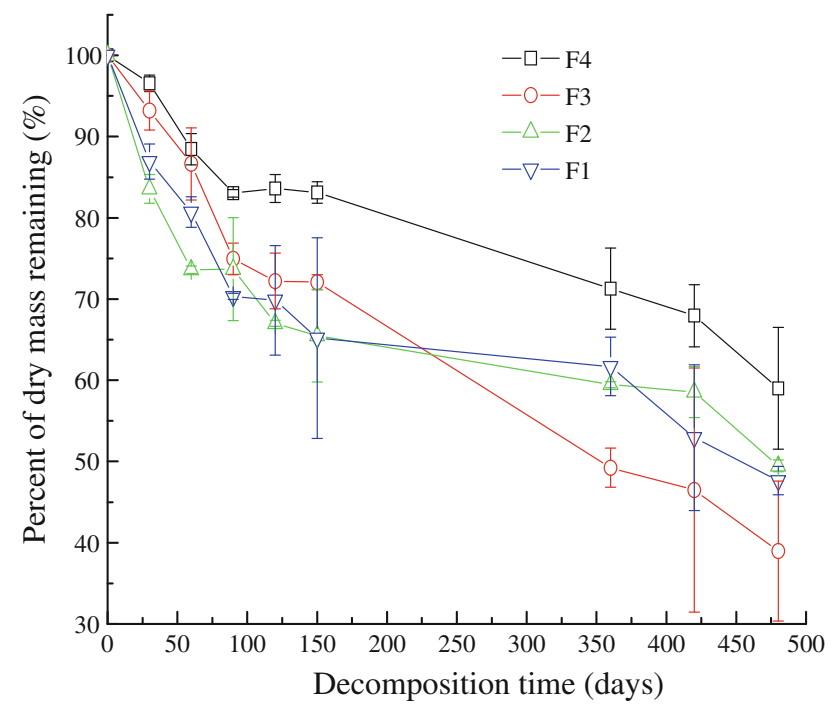

Fig. 3 Percent of dry mass remaining of C. angustifolia litter in the four sites with varying flooding regimes [F1 (perennial flooding, average water depth of 480 days was $40.14 \pm 8.93 \mathrm{~cm}$ ), F2 (perennial flooding, $33.27 \pm 6.67 \mathrm{~cm}$ ), F3 (perennial flooding, $23.23 \pm 5.65 \mathrm{~cm}$ ) and F4 (seasonal flooding, $1.02 \pm 1.09 \mathrm{~cm}$ )] in the waterlogged depression, 25 May 2005-25 September 2006. Values are means $( \pm \mathrm{SD}, n=5)$

higher than those in the seasonal flooding regime (Fig. 5), but the $\mathrm{C} / \mathrm{N}$ or $\mathrm{C} / \mathrm{P}$ ratios in litter of the four flooding regimes had no significant differences $(p>0.05)$. The $\mathrm{C} / \mathrm{N}$ ratios in litter during the decomposition were 83.46$225.52 \%$ for $\mathrm{F} 4,53.23-124.27 \%$ for $\mathrm{F} 3,46.77-140.13 \%$ for F2 and 62.60-114.82\% for F1 compared with the initial values, and the $\mathrm{C} / \mathrm{P}$ ratios in litter of the four flooding regimes accounted for 46.26-265.14, 100.00-278.25, $100.00-195.85$ and $100.00-228.41 \%$ of the initial values, respectively, indicating that, in the perennial flooding regimes, $\mathrm{N}$ might accumulate more in the litter, while $\mathrm{P}$ might release from the litter at all times.

\section{Dynamics of nitrogen or phosphorus accumulation index}

The NAI and PAI of $C$. angustifolia litter in the four flooding regimes had different change characteristics (Fig. 6). In general, the variations of NAI or PAI in F3, F2 and $\mathrm{F} 1$ were consistent, while those in $\mathrm{F} 4$ were different. During the decomposition, the net $\mathrm{N}$ released from the litter at all times in F4, while in F3 and F2, the net N accumulated only in 30 and 120 days. Similarly, in F1, the net $\mathrm{N}$ accumulation only occurred in 120 days. In contrast with that, the net $\mathrm{P}$ released from the litter in F3, F2 and F1 at all times, while in $\mathrm{F} 4$, the net $\mathrm{P}$ release predominated although $\mathrm{P}$ accumulation occurred in 30 and 60 days. ANOVA showed that the NAI of $C$. angustifolia litter in the four sites had no significant differences, while the differences of PAI were significant $(p<0.05)$. The percent of mass remaining $\left(W_{\mathrm{t}} / W_{0}\right)$ had significantly positive correlation with PAI in the four sites $(p<0.05$ or $p<0.01)$, while the correlation between $W_{\mathrm{t}} / W_{0}$ and NAI was significant only in $\mathrm{F} 4(p<0.05)$ (Table 3$)$, indicating that the changes of $\mathrm{P}$ absolute amount in litter of the four sites, to a great extent, probably depended on the mass remaining amount, while those of $\mathrm{N}$ absolute amount in litter of F3, F2 and F1 might depend on other affecting factors, such as $\mathrm{N}$ sources in decomposition environment, microbe immobilization and exchange adsorption of organic matter.

\section{Discussion}

Dynamics of litter decomposition

This study showed that flooding regimes had important effects on the decomposition of $C$. angustifolia litter, the decomposition rates differed among the four water regimes, in the order of F3 $>\mathrm{F} 1>\mathrm{F} 2>\mathrm{F} 4$, and the values in the perennial flooding regimes were much higher. Lin et al. (2004) found that dissolved oxygen (DO) depletion associated with organic matter decomposition took place rapidly in the floodwater inundating the soils. Neckles and Neill (1994) also indicated that the litter in wetland generally decomposed faster when flooded than un-flooded or infrequently flooded, and the positive effect of flooding on litter decomposition might be due to the maintenance of adequate soil moisture for microbial/fungal colonization and activity. In general, water condition affects the decomposition rate of organic matter indirectly through altering the aeration of litter (Cai 2000), and the effect of water condition change on the decomposition depends on the potential change magnitude as well as the current water condition (Chen 1999). If the current water condition is favor for litter decomposition, then the significant water condition change may result in a decrease in decomposition. However, if water is the limiting factor,
Table 2 Linear equations and parameters between the natural logarithm ( $y$ ) of mass remaining and decomposition days $(t)$

\begin{tabular}{lllllll}
\hline Sites & Equations & $k$ & $R^{2}$ & $p$ & $\begin{array}{l}\text { Decomposition } \\
\text { time (days) }\end{array}$ & $t_{0.95}(\mathrm{yr})$ \\
\hline F1 & $y=-0.14280-0.001210 t$ & 0.001210 & 0.8694 & 0.0002 & 480 & 6.88 \\
F2 & $y=-0.17715-0.001040 t$ & 0.001040 & 0.8162 & 0.0008 & 480 & 8.00 \\
F3 & $y=-0.05080-0.001820 t$ & 0.001820 & 0.9825 & $<0.0001$ & 480 & 4.57 \\
F4 & $y=-0.04359-0.000917 t$ & 0.000917 & 0.9442 & $<0.0001$ & 480 & 9.07 \\
\hline
\end{tabular}




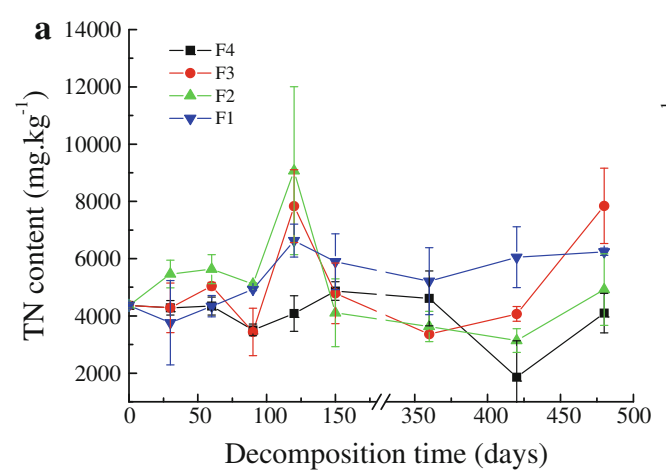

Fig. 4 Changes of TN (a) and TP (b) content in the C. angustifolia litter in the four sites with varying flooding regimes [F1 (perennial flooding, average water depth of 480 days was $40.14 \pm 8.93 \mathrm{~cm}$ ), F2 (perennial flooding, $33.27 \pm 6.67 \mathrm{~cm}$ ), F3 (perennial flooding,

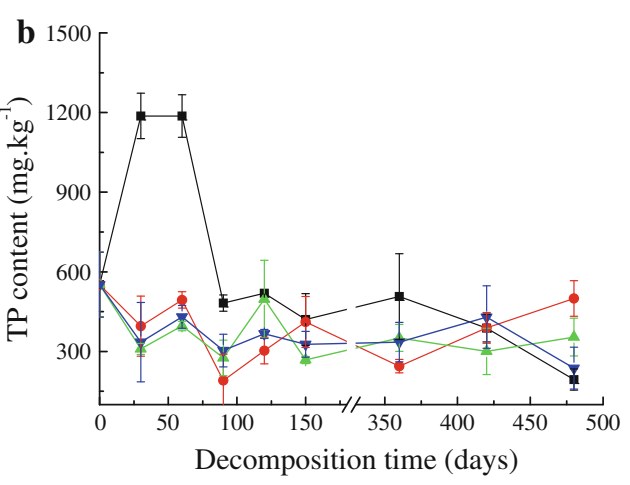

$23.23 \pm 5.65 \mathrm{~cm}$ ) and F4 (seasonal flooding, $1.02 \pm 1.09 \mathrm{~cm}$ )] in the waterlogged depression, 25 May 2005-25 September 2006. Values are means $( \pm \mathrm{SD}, n=5)$

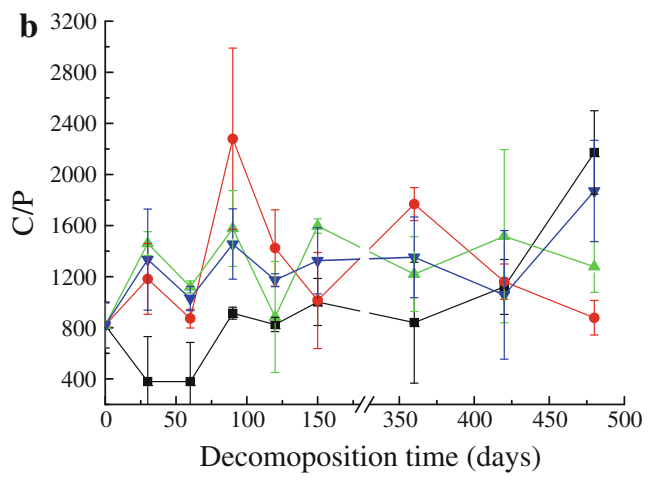

(perennial flooding, $23.23 \pm 5.65 \mathrm{~cm}$ ) and F4 (seasonal flooding, $1.02 \pm 1.09 \mathrm{~cm}$ )] in the waterlogged depression, 25 May 2005-25 September 2006. Values are means $( \pm \mathrm{SD}, n=5)$

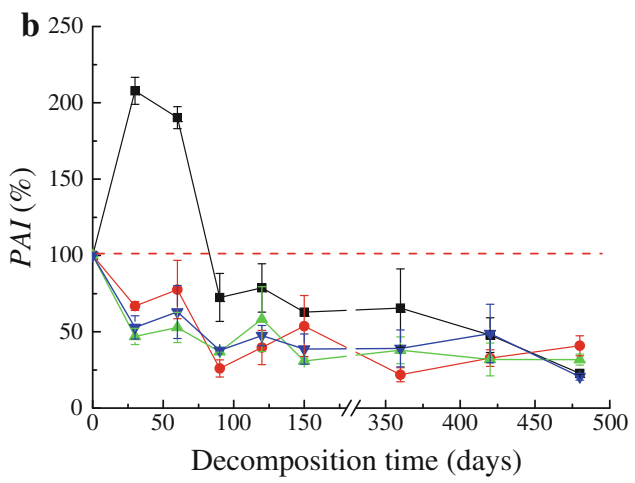

$23.23 \pm 5.65 \mathrm{~cm}$ ) and F4 (seasonal flooding, $1.02 \pm 1.09 \mathrm{~cm}$ )] on the waterlogged depression, 25 May 2005-25 September 2006. Values are means $( \pm \mathrm{SD}, n=5)$

weak perennial flooding regimes (F3), the decomposition rate rapidly increased. This showed that water was a limiting factor in $\mathrm{F} 1$, and the proper increase of water position (Chen et al. 2001). In current water condition (F4), the $C$. angustifolia litter decomposed slowest, while in 
Table 3 Correlation coefficients between percent of mass remaining $\left(W_{\mathrm{t}} / W_{0}\right)$ and accumulation index $(\mathrm{AI})$

\begin{tabular}{|c|c|c|c|c|}
\hline \multirow{2}{*}{$\begin{array}{l}\text { Accumulation index } \\
(\mathrm{AI}, \%)\end{array}$} & \multicolumn{4}{|c|}{ Percent of mass remaining $(\%)$ in the four sites } \\
\hline & F1 & $\mathrm{F} 2$ & F3 & $\mathrm{F} 4$ \\
\hline NAI & 0.366 & 0.593 & 0.574 & $0.776^{*}$ \\
\hline PAI & $0.855 * *$ & $0.829 * *$ & $0.780 * *$ & $0.727 *$ \\
\hline
\end{tabular}

* Correlation is significant at the 0.05 level

** Correlation is significant at the 0.01 level

condition in F3 was in favor of decomposition. On the other hand, the litter decomposition rate in strong or medium perennial flooding regime (F1, F2) was much lower than that in weak perennial flooding regime $(\mathrm{F} 3)$, indicating that the water regime in $\mathrm{F} 3$ was favor for decomposition, and the significant increase of water condition in $\mathrm{F} 2$ and $\mathrm{F} 1$ resulted in obvious decrease in decomposition through affecting the status of $\mathrm{O}_{2}$ and $\mathrm{CO}_{2}$ in litter. With the great increase of water in decomposition environment, the $\mathrm{O}_{2}$ in litter would be depleted rapidly and the metabolism of decomposition microbes would be restrained (Laiho et al. 2004). In addition, the lower decomposition rates of litter also might be attributed to the low rate of enzymic decomposition (Freeman et al. 2004). As the devoid of molecular oxygen, the enzymes such as phenol oxidase, which required molecular oxygen for their activity, were rarely active, and thus inhibited the decomposition of organic matter. Anderson and Smith (2002) studied the effect of flooding regimes on decomposition of $P$. pensylvanicum litter in playa wetlands, and also found that the litter decomposition rates were generally lowest in the strong or medium flooded conditions and highest in the weak flooded conditions.

The litter decomposition rates are also significantly affected by environment temperature, and the values generally increased with increasing temperature (Cai 2000). Our study showed the similar result. In summer and fall, the $C$. angustifolia litter decomposed rapidly, while in winter and early spring, the litter decomposed slowly, and the correlation between environment temperature and decomposition rate in the four sites were mostly positive (Table 4). The acidity-alkalinity status also may have great effects on litter decomposition as microbes all have different optimum $\mathrm{pH}$ ranges, and higher or lower $\mathrm{pH}$ may significantly inhibit microbe activities (Cai 2000). Hohmann and Neely (1993) indicated that the increase of acidity could inhibit the decomposition of Sparganium eurycarpum litter, and the dry weight remaining after 200 days at $\mathrm{pH} 4,6$ and 8 were 47.5, 27.9 and 7.3\%, respectively. Leuven and Wolfs (1988) found that the $\mathrm{pH}$ particularly influenced the decomposition rate of Juncus bulbosus L. litter, and in control media with $\mathrm{pH} 3.5$ and 5.6, the total organic weight losses after 37 days were 55
Table 4 Correlation coefficients between environment temperature and relative decomposition rate

\begin{tabular}{lllll}
\hline Items & F1 & F2 & F3 & F4 \\
\hline Atmospheric temperature & 0.677 & 0.218 & 0.598 & 0.440 \\
Surface ground/water temperature & 0.584 & 0.390 & 0.581 & 0.643 \\
$5 \mathrm{~cm}$ ground/water temperature & 0.265 & 0.146 & 0.441 & 0.700 \\
$10 \mathrm{~cm}$ ground/water temperature & 0.208 & -0.109 & 0.403 & 0.584 \\
$20 \mathrm{~cm}$ ground/water temperature & 0.235 & -0.003 & 0.234 & 0.436 \\
\hline
\end{tabular}

and $59 \%$, respectively. In this study, the $\mathrm{pH}$ of water or soil in the four sites ranged from 5.36 to 6.37 , implying that the acidity status of decomposition environments might have different effects on the litter decomposition, but these effects still need to be studied.

In general, the chemical properties of litter (mainly include $\mathrm{N}, \mathrm{P}$, lignin and cellulose contents, $\mathrm{C} / \mathrm{N}$, lignin/ $\mathrm{N}$ and $\mathrm{C} / \mathrm{P}$ ratios) are the main control factors of decomposition. Among them, the $\mathrm{C} / \mathrm{N}$ and lignin/ $\mathrm{N}$ ratios are the best predication indices of decomposition rate as they reflect the ratio of carbohydrate and lignin to protein in litter (Harmon et al. 1990; Hobbic 1996; Chen 1999). However, the predication indices of decomposition in different stages differ with the changes of litter substrate quality. Alerts and Caluwe (1997) found that the litter decomposition was strongly limited by $\mathrm{C} / \mathrm{P}$ ratio in the initial stage, while closely correlated with the ratios of phenolic compounds/N and phenolic compounds/P in long-term decomposition. In this experiment, the $\mathrm{C} / \mathrm{N}$ and $\mathrm{C} / \mathrm{P}$ ratios had different effects on the litter decomposition in the four sites. In most instances, the $\mathrm{C} / \mathrm{N}$ or $\mathrm{C} / \mathrm{P}$ ratios had negative correlations with decomposition rates (Table 5), which indicated that the higher of $\mathrm{C} / \mathrm{N}$ or $\mathrm{C} / \mathrm{P}$ ratios, the slower of decomposition rates and the result was close to the reports mentioned previously (Harmon et al. 1990; Hobbic 1996; Chen 1999; Yang et al. 2006; Wu et al. 2007). On the other hand, the $\mathrm{C} / \mathrm{N}$ or $\mathrm{C} / \mathrm{P}$ ratios, in $\mathrm{F} 3$ and $\mathrm{F} 1$, had positive correlations with decomposition rates and the correlation in $\mathrm{F} 1$ was significant $(p<0.05)$, implying that the status of $\mathrm{N}$ and $\mathrm{P}$ nutrient in the decomposition environment probably influenced the litter decomposition. Davis (1991) studied the decomposition of Cladium jamaicense and $T$. domingensis litters in Florida Everglades, and found that the decomposition was lowest under non-enriched conditions and reached a maximum under a moderate level of enrichment. Verhoeven and Arts (1992) studied the Carex litter decomposition in mires with different water chemistry, and found that the conditions for cellulose decay are much more suitable in the groundwater fed (base-rich) fen dominated by Carex diandra than in the rainwater fed (base-poor) fen with Carex acutiformis. In addition, the increase of $\mathrm{N}$ and $\mathrm{P}$ supply in the decomposition environment also have great 
Table 5 Correlation coefficients between $\mathrm{C} / \mathrm{N}$ or $\mathrm{C} / \mathrm{P}$ ratio and relative decomposition rate

\begin{tabular}{lllll}
\hline Items & $\mathrm{F} 1$ & $\mathrm{~F} 2$ & $\mathrm{~F} 3$ & $\mathrm{~F} 4$ \\
\hline $\mathrm{C} / \mathrm{N}$ & $0.779^{*}$ & -0.517 & 0.377 & -0.083 \\
$\mathrm{C} / \mathrm{P}$ & -0.017 & -0.282 & 0.561 & -0.110 \\
\hline
\end{tabular}

* Correlation is significant at the 0.05 level

effects on the litter decomposition as this increase may alter the $\mathrm{C} / \mathrm{N}$ or $\mathrm{C} / \mathrm{P}$ ratios of litter. Aerts and Caluwe (1994) indicated that, in the area of abundant $\mathrm{N}$ deposition, the increase of $\mathrm{N}$ import might accelerate the litter decomposition. Xie et al. (2004) studied the effects of $\mathrm{N}$ and $\mathrm{P}$ availability on the decomposition of aquatic plants, and found that the elevation of P-availability greatly increased the decomposition rate of Eichhornia crassipes by $68-87 \%$, whereas the impact of $\mathrm{N}$-availability was insignificant, implying that the responses of decomposition to nutrient availability depended on nutrient type. As mentioned previously, the $\mathrm{N}$ and $\mathrm{P}$ nutrient status in the marsh water of $\mathrm{F} 3$, F2 and F1 were different, which might affect the corresponding litter decomposition rate. In addition, the physiognomy of waterlogged depression was declined in turn along with the direction of F3 $\rightarrow$ F2 $\rightarrow$ F1, indicating that the exchange of marsh water in the three sites might occur if the flooding regimes changed significantly resulting from the increase or decrease of precipitation during the experiment. During the exchange of marsh water, the nutrient among the three sites would be changed simultaneously, and the ultimate results caused the nutrient status in the marsh water of each decomposition site, compared with its original environment, changed greatly. Therefore, based on above-mentioned analysis, we could conclude that the decomposition rates, to some extent, depended on the substrate quality indices of the litter if the nutrient status of decomposition environment did not change greatly. Conversely, if the nutrient status changed greatly due to nutrient deposition and nutrient exchange among marsh water, the decomposition rates, to a great extent, depended on the supply status of nutrient in the decomposition environment.

Nutrient dynamics in litter decomposition process

This study showed that flooding regimes also had important effects on the $\mathrm{N}$ and $\mathrm{P}$ dynamics of $C$. angustifolia litter in decomposition process, and in the perennial flooding regimes, the $\mathrm{N}$ might accumulate more in the litter, while $\mathrm{P}$ might release from the litter at all times. Some relative studies also showed similar results. Dick and Osunkoya (2000) found that the C and N contents in Avicennia marina litter were much higher in tidal wetland than those of landward wetland as the difference in water conditions. Wrubleski et al. (1997) found that the P in litters (T. glauca, $P$. australis, S. festucacea and S. lacustris) in different flood conditions $(1-30 \mathrm{~cm}, 31-60 \mathrm{~cm}$ and $>60 \mathrm{~cm}$ water depths) exhibited significant losses (46.3-92.7\%) during the first 112 days. In this experiment, the changes of $\mathrm{N}$ and $\mathrm{P}$ content in the litter of the four sites might be related to the different nutrient status in marsh water (Fig. 2). Sun et al. (2006) found that the N/P ratio of $C$. angustifolia was $5.99 \pm 0.20$, indicating that the marsh was limited by $\mathrm{N}$ (Tessier and Raynal 2003). Therefore, in some periods, the increase of $\mathrm{N}$ content in litter in the perennial flooding regimes might be attributed to the $\mathrm{N}$ immobilization by microbes from marsh water (Liu et al. 2000). Similarly, Gessner (2000) found that the N concentrations tended to increase in the leaf, culm and sheath of Pragmites australis litter, and the reasons were mainly related to the external biological immobilization from lake water. Another study by Gessner (2001) indicated that the microbial immobilization was a very important process controlling the nutrient dynamics of litter during decomposition, which was mainly regulated by the $\mathrm{C} / \mathrm{N}$ ratios in the litter and the $\mathrm{N}$ availability in the decomposition environment (Berg 1986; Köchy and Wilson 1997). The $\mathrm{C} / \mathrm{N}$ ratios had significant negative correlations with $\mathrm{N}$ contents $(p<0.01)$ (Table 6), but the correlations between $\mathrm{C} / \mathrm{N}$ ratios and $\mathrm{P}$ contents were not significant, indicating that the $\mathrm{C} / \mathrm{N}$ ratios might control the $\mathrm{N}$ dynamics in the litter of the four sites. The $\mathrm{C} / \mathrm{N}$ ratios in the litter of the four sites were all much lower, and the $\mathrm{N}$ in the litter could meet the demand of organisms, thus the superfluous $\mathrm{N}$ would release from the litter in most periods.

As analyzed previously, the net $\mathrm{P}$ released from the litter in F3, F2 and F1 at all times, while in F4, the net P release predominated although $\mathrm{P}$ accumulation occurred in 30 and 60 days, and the reasons were related to the $\mathrm{P}$ loss by leaching (Puriveth 1980). Previous studies indicated that the $\mathrm{P}$ was easily lost due to leaching because $\mathrm{P}$ mainly existed in phosphates in plant tissues (Wen et al. 1998). Based on above analysis, the marsh was not limited by $\mathrm{P}$, and
Table 6 Correlation coefficients between $\mathrm{C} / \mathrm{N}$ or $\mathrm{C} / \mathrm{P}$ ratio and nitrogen or phosphorus

** Correlation is significant at the 0.01 level

\begin{tabular}{|c|c|c|c|c|c|c|c|c|}
\hline \multirow[t]{2}{*}{ Items } & \multicolumn{4}{|l|}{$\mathrm{N}$} & \multicolumn{4}{|l|}{$\mathrm{P}$} \\
\hline & F1 & $\mathrm{F} 2$ & F3 & $\mathrm{F} 4$ & $\mathrm{~F} 1$ & $\mathrm{~F} 2$ & F3 & $\mathrm{F} 4$ \\
\hline $\mathrm{C} / \mathrm{N}$ & $-0.989 * *$ & $-0.923 * *$ & $-0.968 * *$ & $-0.977 * *$ & 0.357 & -0.369 & -0.442 & -0.205 \\
\hline $\mathrm{C} / \mathrm{P}$ & 0.330 & -0.486 & -0.390 & -0.177 & $-0.949 * *$ & $-0.979 * *$ & $-0.954 * *$ & $-0.807 * *$ \\
\hline
\end{tabular}


therefore, the demand of decomposers was not limited by $\mathrm{P}$ supply during the decomposition. As a result, superfluous $\mathrm{P}$ would retard microbial activities, causing $\mathrm{P}$ to release from the litter. In this study, the $\mathrm{C} / \mathrm{P}$ ratios had significant negative correlations with $\mathrm{P}$ contents $(p<0.01)$ (Table 6$)$, but the correlations between $\mathrm{C} / \mathrm{P}$ ratios and $\mathrm{N}$ contents were not significant, indicating that the $\mathrm{C} / \mathrm{P}$ ratios might control the $\mathrm{P}$ dynamics in the litter of the four sites. This study also showed that, in the perennial flooding regimes, the net $\mathrm{P}$ release amounts were much higher than those in the seasonal flooding regime (Fig. 6b), and the reasons were mainly related to the $\mathrm{P}$ nutrient status in the decomposition environment. In general, the lower the $\mathrm{C} / \mathrm{P}$ ratios, the more the $\mathrm{P}$ release (Yang et al. 2006). Although the $\mathrm{C} / \mathrm{P}$ ratios in the litter of the perennial flooding regimes were higher than those in the seasonal flooding regime (Fig. 5b), the relatively abundant $\mathrm{P}$ nutrient in marsh water might reduce the $\mathrm{C} / \mathrm{P}$ ratios, and thus cause the litter release more $\mathrm{P}$.

\section{Conclusion}

The decomposition experiment of $C$. angustifolia litter in different flooding regimes has demonstrated that: (i) flooding regimes had important effects on the litter decomposition, the decomposition rates differed among the four sites, in the order of $\mathrm{F} 3>\mathrm{F} 1>\mathrm{F} 2>\mathrm{F} 4$. Flooding regimes also had significant effects on the $\mathrm{N}$ and $\mathrm{P}$ dynamics of litter in decomposition process; (ii) If the perennial flooding regimes were formed in $C$. angustifolia wetland in the future, the litter mass loss would increase 23.28-48.88\%, the decomposition rate would increase $13.41-98.47 \%$, and the $t_{0.95}$ would decrease $1.07 \mathrm{yr}-4.50 \mathrm{yr}$. In the perennial flooding regimes, the net $\mathrm{N}$ accumulated in some periods, while the net $\mathrm{P}$ released at all times; (iii) the decomposition rates in the four flooding regimes depended on the substrate quality indices of the litter if the nutrient status of the decomposition environment did not change greatly. Conversely, if the nutrient status changed greatly, the decomposition rates probably depended on the supply status of nutrient in the decomposition environment; (iv) the changes of $\mathrm{N}$ and $\mathrm{P}$ content in the litter of the four flooding regimes were related to the $\mathrm{C} / \mathrm{N}$ or $\mathrm{C} / \mathrm{P}$ ratios in the litter and the $\mathrm{N}$ or $\mathrm{P}$ availability in the decomposition environment. In the perennial flooding regimes, the increase of $\mathrm{N}$ content in the litter in some periods might be attributed to the $\mathrm{N}$ immobilization by microbes from marsh water, while more $\mathrm{P}$ released from the litter might be related to the alteration of $\mathrm{C} / \mathrm{P}$ ratios in the litter due to the change of $\mathrm{P}$ nutrient in the decomposition environment.

Acknowledgments The authors would like to acknowledge the financial support of the National Nature Science Foundation of China
(No. 40803023, 41171424), the Key Program of Natural Science Foundation of Shandong Province (No. ZR2010DZ001), the Innovation Program of the Chinese Academy of Sciences (No. KZCX2YW-223; KZCX3-SW-332), and the Strategy Guidance Program of the Chinese Academy of Sciences (No. XD05030404).

Open Access This article is distributed under the terms of the Creative Commons Attribution Noncommercial License which permits any noncommercial use, distribution, and reproduction in any medium, provided the original author(s) and source are credited.

\section{References}

Aerts R, Caluwe HD (1994) Effects of nitrogen supply on canopy structure and leaf nitrogen distribution in Carex Species. Ecology 75:1482-1490

Alerts R, Caluwe HD (1997) Nutritional and plant mediated controls on leaf litter decomposition of Carex species. Ecology 78:244-260

Alwyn S, Herbert B, Andrew SB (2005) Elevated atmospheric $\mathrm{CO}_{2}$ affects the turnover of nitrogen in a European grassland. Appl Soil Ecol 28:37-46

Anderson JT, Smith LM (2002) The effects of flooding regimes on decomposition of Polygonum pensylvanicum in playa wetlands (Southern Great Plains, USA). Aquat Bot 74:97-108

Berg B, Johnsson MB, Meentemeyer V (2000) Litter decomposition in a transect of Norway spruce forests: substrate quality and climate control. Can J Forest Res 30:1136-1147

Berg B (1986) Nutrient release from litter and humus in coniferous forest soils - a mini review. Scand J Forest Res 1:359-369

Bouchard V, Lefeuvre JC (2000) Primary production and macrodetritus dynamics in a European salt marsh: carbon and nitrogen budgets. Aquat Bot 67:23-42

Cai XM (2000) Ecosystem ecology. Science Press, Beijing

Chen GQ (1996) The study of marsh in the Sanjiang Plain. Science Press, Beijing

Chen H, Harmon ME, Tian HQ (2001) Effects of global change on litter decomposition in terrestrial ecosystems. Acta Ecol Sin 21(9):1549-1562

Chen H (1999) Root decomposition in three coniferous forest: effects of substrate quality, temperature, and moisture. PhD dissertation, Oregon State University

Chen YY (1995) Study on the wetland of China. Jilin Science and Technology Press, Changchun

Cotrufo MF, Briones MJI, Ineson P (1998) Elevated $\mathrm{CO}_{2}$ affects field decomposition rate and palatability of tree leaf litter: importance of changes in substrate quality. Soil Biol Biochem 30(12): 1565-1571

Davis SM (1991) Growth, decomposition, and nutrient retention of Cladium jamaicense Crantz and Typha domingensis Pers. in the Florida Everglades. Aquat Bot 40(3):203-224

Dick TM, Osunkoya OO (2000) Influence of tidal restriction floodgates on decomposition of mangrove litter. Aquat Bot 68: 273-280

Dilustro JJ, Day FP, Drake BG, Hinkle CR (2002) Abundance, production and mortality of fine roots under elevated atmospheric $\mathrm{CO}_{2}$ in an oak-scrub ecosystem. Environ Exp Bot 48: 149-159

Edward GT, Day FP (1990) Decomposition of roots in a seasonally flooded swamp ecosystem. Aquat Bot 37(3):199-214

Finzi AC, Allen AS, Delucia EH, Ellsworth DS, Schlesinger WH (2001) Forest litter production, chemistry, and decomposition following two years of free-air $\mathrm{CO}_{2}$ enrichment. Ecology 82(2):470-484 
Freeman C, Ostle NJ, Fenner N, Kang H (2004) A regulatory role for phenol oxidase during decomposition in peatlands. Soil Biol Biochem 36:1663-1667

Gao JQ, Ouyang H, Lu XG, Wang G (2004) Study on litter decomposition and influence factors in Calamagrostis angustifolia wetland in Sanjiang Plain. J Soil Water Conserv 18(4): $121-124$

Gessner MO (2000) Breakdown and nutrient dynamics of submerged Phragmites shoots in the littoral zone of a temperate hardwater lake. Aquat Bot 66(1):9-20

Gessner MO (2001) Mass loss, fungal colonization and nutrient dynamics of Phragmites austrialis leaves during senescence and early aerial decay. Aquat Bot 69(2-4):325-339

Haraguchi A, Hasegawa C, Hirayama A, Kojima H (2003) Decomposition activity of peat soils in geogenous mires in Sasaka mi, Central Japan. Eur J Soil Biol 39:191-196

Haraguchi A, Kojima H, Hasegawa C, Takahashi Y, Lyobe T (2002) Decomposition of organic matter in peat soil in a minerotrophic mire. Eur J Soil Biol 38:89-95

Harmon ME, Baker GA, Spycher G, Greene SE (1990) Leaf litter decomposition in the Picea-Tsuga forest of Olympic National Park, Washington, USA. Eur J Soil Biol 31:55-66

He L (2000) The Sanjiang Plain of China. Heilongjiang Science and Technology Press, Harbin

Hobbic SH (1996) Temperature and plant species control over litter decomposition in Alaskan Tundra. Ecol Monogr 66:503-522

Hohmann J, Neely RK (1993) Decomposition of Sparganium eurycarpum under controlled $\mathrm{pH}$ and nitrogen regimes. Aquat Bot 46(1):17-33

Holmboe N, Kristensen E, Andersen FØ (2001) Anoxic decomposition in sediments from a tropical mangrove forest and the temperate Wanden Sea: implications of $\mathrm{N}$ and $\mathrm{P}$ addition experiments. Estuar Coast Shelf Sci 53:125-140

IPCC (2007) Changes in atmospheric constituents and in radioactive forcing. In: Climate change: the physical science basis. Contribution of working group $i$ to the fourth assessment report of the intergovernmental panel on climate change. Cambridge University Press, Cambridge

Ji YH (2004) The Chang characteristic of species diversity of typical wetland plant community in the Sanjiang Plain. Master degree dissertation, Graduate School of the Chinese Academy of Sciences, Beijing, pp 34-60

Jiang ZH, Chen WL, Song J, Wang J (2009) Projection and evaluation of the precipitation extremes indices over China based on seven IPCC AR4 coupled climate models. Chin J Atmos Sci 33(1):109-120

Köchy M, Wilson SD (1997) Litter decomposition and nitrogen dynamics in Aspen forest and mixed-grass prairie. Ecology 78(3):732-739

Laiho R, Laine J, Trettin CC, Finer L (2004) Scots pine litter decomposition along drainage succession and soil nutrient gradients in peatland forests, and the effects of inter-annual weather variation. Soil Biol Biochem 36:1095-1109

Leuven RSEW, Wolfs WJ (1988) Effects of water acidification on the decomposition of Juncus bulbosus L. Aquat Bot 31(1-2): $57-81$

Lin C, Wood M, Haskins P, Ryfel T, Lin J (2004) Controls on water acidification and de-oxygenation in an estuarine waterway, Eastern Australia. Estuar Coast Shelf Sci 61:55-63

Liu JS, Sun XL, Yu JB (2000) Nitrogen content variation in litters of Deyeuxia angustifolia and Carex lasiocarpa in Sanjiang Plain. Chin J Appl Ecol 11(6):898-902

Liu JS, Yang JS, Yu JB, Wang JD (2003) Study on vertical distribution of soil organic carbon in wetlands, Sanjiang Plain. J Soil Water Conserv 17(3):5-8
Liu J, Han Y, Cai ZC (2009) Decomposition and products of wheat and rice straw from a FACE experiment under flooded conditions. Pedosphere 19(3):389-397

Lu T, Ma KM, Fu BJ, Ni HW (2008) Effects of ditch network structure on landscape patter in the Sanjiang Plain, Northeast China. Acta Ecol Sin 28(6):2746-2752

Marhan S, Demin D, Erbs M, Kuzyakov Y, Fangmeier A, Kandeler E (2008) Soil organic matter mineralization and residue decomposition of spring wheat grown under elevated $\mathrm{CO}_{2}$ atmosphere. Agric Ecosyst Environ 123:63-68

Mendelssohn IA, Sorrell BK, Brix H, Schierup H, Lorenzen B, Maltby E (1999) Controls on soil cellulose decomposition along a salinity gradient in a Phragmites australis wetland in Denmark. Aquat Bot 64:381-398

Neckles HA, Neill C (1994) Hydrologic control of litter decomposition in seasonally flooded prairie marshes. Hydrobiologia 286:155-165

Nielsen T, Andersen FØ (2003) Phosphorus dynamics during decomposition of mangrove (Rhizophora apiculata) leaves in sediments. J Exp Mar Biol Ecol 293:73-88

Olson JS (1963) Energy storage and the balance of products and decomposers in ecological systems. Ecology 44(2):322-331

Owensby CE (1993) Nitrogen and phosphorus dynamics of a tallgrass prairie ecosystem exposed to elevated carbon dioxide. Plant Cell Environ 16:843-850

Peng SL, Liu Q (2002) The dynamics of forest litter and its responses to global warming. Acta Ecol Sin 22(9):1534-1544

Pereira P, Cacador I, Vale C, Caetano M, Costa A (2007) Decomposition of belowground litter and metal dynamics in salt marshes (Tagus Estuary, Portugal). Sci Total Environ 380:93-101

Puriveth P (1980) Decomposition of emergent macrophytes in a Wisconsin marsh. Hydrobiologia 72(3):231-242

Sowerby A, Blum H, Ball AS (2005) Elevated atmospheric $\mathrm{CO}_{2}$ affects the turnover of nitrogen in a European grassland. Appl Soil Ecol 28:37-46

Sun ZG, Liu JS, Wang JD, Qin SJ (2006) Biomass structure and nitrogen and phosphorus contents of Calamagrostis angustifolia populations in different communities of Sanjiang Plain. Chin J Appl Ecol 17(2):221-228

Tam NEY, Wong YS, Lan CY, Wang LN (1998) Litter production and decomposition in a subtropical mangrove swamp receiving wastewater. J Exp Mar Biol Ecol 226:1-18

Tessier JT, Raynal DJ (2003) Use of nitrogen to phosphorus ratios in plant tissue as an indicator of nutrient limitation and nitrogen saturation. J Appl Ecol 40(3):523-534

The Committee of Agro-chemistry of the Chinese Society of Soil Science (1983) The conventional analysis methods in soil agrochemistry. Science Press, Beijing, pp 30-150

Vargo SM, Neely RK, Kirkwood SM (1998) Emergent plant decomposition and sedimentation: response to sediments varying in texture, phosphorus content and frequency of deposition. Environ Exp Bot 40:43-58

Verhoeven JTA, Arts HHM (1992) Carex litter decomposition and nutrient release in mires with different water chemistry. Aquat Bot 43:365-377

Villar CA, Cabo L, Vaithiyanathan P, Bonetto C (2001) Litter decomposition of emergent macrophytes in a floodplain marsh of the Lower Paraná River. Aquat Bot 70:105-116

Wang J, Lou DJ, Qu JH, Zhang K (2009) Prediction of climate and utilizable precipitation change in Northeast China by using IPCC-AR4 model date. J Nat Resour 24(9):1647-1656

Wang QB, Li LH, Bai YF (2000) Effects of simulated climate change on the decomposition of mixed litter in three steppe communities. Acta Phytoecol Sin 24(6):674-679 
Welsch M, Yavitt JB (2003) Early stages of decay of Lythrum salicaria L. and Typha latifolia L. in a standing-dead position. Aquat Bot 75:45-57

Wen DZ, Wei P, Zhang YC, Kong GH (1998) Dry mass loss and chemical changes of the decomposed fine roots in three China south subtropical forests at Dinghushan. Chin J Ecol 17(2):1-6

Wrubleski DA, Murkin HR, van der Valk AG, Nelson JW (1997) Decomposition of emergent macrophyte roots and rhizomes in a northern prairie marsh. Aquat Bot 58(2):121-134

Wu HT, Lu XG, Yang Q, Jiang M, Tong SZ (2007) Early-stage litter decomposition and its influencing factors in the wetland of the Sanjiang Plain, China. Acta Ecol Sin 27(10):4027-4035

Xie YH, Yu D, Ren B (2004) Effects of nitrogen and phosphorus availability on the decomposition of aquatic plants. Aquat Bot 80:29-37
Yang JS, Liu JS, Yu JB, Wang JD, Li XH, Sun ZG (2006) Decomposition and nutrient dynamics of marsh litter in the Sanjiang Plain, Northeast China. Acta Ecol Sin 26(5):1297-1302

Yang Q, Lu XG (1996) Kinds of soil and their characteristics in the ecological experimental area of mire-wetlands. In: Chen GQ (ed) The study of marsh in the Sanjiang Plain. Science Press, Beijing

Yin CJ, Hang DH, Chen ZZ (1994) Quantitative relationships between the litter decomposition of four species in inner Mongolia grassland and climatic factors. Acta Ecol Sin 14(2):149-154

Zhang YZ (1988) The genesis, nature and classification of the marsh soil in the Sanjiang Plain. In: Huang XC (ed) The study of marsh in China. Science Press, Beijing 